\title{
Biografie polsko-żydowskie i żydowsko-polskie: rekonesans ponawiany
}

W ostatnich latach zaobserwować można gwałtowny rozwój biografistyki, a zjawisko to wiąże się nie tylko ze wzrostem liczby wydawanych książek o życiu sławnych osób, ale i z przemianami w sposobie tworzenia oraz czytania tego typu publikacji. Badacze zgodnie i powszechnie ogłaszają koniec obowiązującego przez wiele dekad modelu biografii - portretów kreowanych z powściągliwością i dystansem oraz życiorysów, w których wszelkie niewygodne fakty pomijane bywały milczeniem. Irena Grudzińska-Gross, wskazując na wyraziste w zachodniej kulturze tendencje przełamywania biograficznego tabu, w polskiej przestrzeni literackiej za utwór przełomowy uznała budzącą wiele kontrowersji książkę Artura Domosławskiego. Stwierdziła przy tym: „Kapuściński non-fiction stanowił przełom i, sądząc z reakcji czytelników, powrót do poprzedniej biograficznej poprawności nie będzie już możliwy" .

Pryskające osłony dyskrecji zdaniem Grudzińskiej-Gross zmieniają relację między autorem i jego bohaterem. Twórca biografii powinien dziś mieć „spojrzenie raczej bezlitosne”, a trzeźwość osądu powinna iść $\mathrm{w}$ parze $\mathrm{z}$ faktograficzną precyzją: „Gusta, impulsy, dewiacje, fascynacje stały się integralną częścią obrazu osoby, w tym także twórcy. Czytelnik interesuje się teraz tym, co ukryte, podświadome, głębokie. [...] Biograf ma tę przewagę nad swym bohaterem, że jak aparat rentgenowski prześwietla go na wskroś, a w każdym razie usiłuje to robić” ${ }^{2}$. Jednocześnie jednak zmienił się odbiór takich dzieł: ciekawości towarzyszy wątpienie, odkrywaniu tajemnic - nieufność wobec możności ich rzeczywistego zgłębienia. Zarówno autorzy,

\footnotetext{
I I. Grudzińska-Gross, Rentgen nie zna litości, „Książki” 2011, nr 1, s. 14.

${ }^{2}$ Ibidem.
} 
jak i czytelnicy wiedzą już, że każda narracja zostaje naznaczona piętnem indywidualnego oglądu świata, ograniczona przez konwencje i retoryczne mechanizmy języka. Nadto bywa zazwyczaj używana $\mathrm{w}$ określonym celu, warunkowanym $\mathrm{z}$ jednej strony zbiorem osobistych doświadczeń, z drugiej zaś - uświadamianym i nieświadomym potrzebom ekspresji własnego „ja”.

Janina Abramowska, pisząc o mechanizmach autoanalizy i autoprezentacji odsłanianych $\mathrm{w}$ tekstach jawnie autobiograficznych, wskazywała na ewokowaną przez nie „podejrzliwość” odbiorczą, która stała się nieusuwalnym komponentem współczesnej literackiej komunikacji. Dodawała:

Podejrzliwość rozciąga się też na biografie pisarzy tworzone przez świadków i historyków, w tym przez badaczy twórczości. Wypada zgodzić się ze zdaniem Haydena White'a, że każde źródło nosi nieusuwalne subiektywne piętno kogoś, kto je wytworzył, a dyskurs historyczny układa się według quasi-literackich wzorców literackich. Dyskursu biograficznego dotyczy to szczególnie³.

W konsekwencji tak po stronie nadawcy, jak po stronie odbiorcy dzieł biograficznych oraz autobiograficznych można odnaleźć nieufność wpisaną w reguły komunikacyjnego funkcjonowania utworów. Lektura autobiografii kieruje uwagę odbiorcy na motywacje leżące u podstaw decyzji jej spisywania. Podobnie rzecz się ma z biografiami - już sam wybór bohatera biografii skłania do zadawania pytań o osobisty wymiar autorskiego gestu. Wybór ten nie jest przecież przypadkowy, a teksty biograficzne zdają się zdradzać tyle samo o bohaterze, co o autorze, który nierzadko jawnie przyznaje się do powinowactwa, pokrewieństwa, czy nawet identyfikacji z prezentowaną postacią - życiorysem losem.

Piotr Śliwiński pisał o współczesnych biografiach: „Rekonstrukcja i kreacja, wiedza i domysł, odpisywanie, dopisywanie i tworzenie, wszystko to ściśle się splata". Istotny okazuje się poziom autorskiej świadomości reguł i mechanizmów zapośredniczania biograficznej „wiedzy”, który można uznać za podstawę wartościowania tekstów: „Dobra biografia jest $\mathrm{z}$ musu autorska, świadomie nieobiektywna i w związku z tym niearogancka. Zła biografia jest $\mathrm{z}$ wyboru autorska, skrycie nieobiektywna i arogancka" ${ }^{4}$. Tym samym nadbudowywana nad prezentowaną

3 J. Abramowska, Podmiot - osoba - autor, w: Sporne i bezsporne problemy wspótczesnejwiedzyoliteraturze, red. W. Bolecki, R. Nycz, Warszawa 2002, s. 112.

4 P. Śliwiński, Horror poeticus. Szkice, notatki, Wrocław 2012, s. 66. Badacz podaje dalej: „Przykładem pierwszej jest dla mnie Twarz Tuwima Piotra 
biografią sfera autobiograficzna autora może być akceptowana wówczas, gdy wiąże się ze świadomością przyczyn i konsekwencji kreowania takiego specyficznego świadectwa: kontaminowanego na poziomie narracji, a jednocześnie rozszczepiającego się na poziomie odbioru.

Irena Grudzińska-Gross swoje rozważania prowadziła przy okazji omawiania dwóch głośnych, a zarazem (znów) kontrowersyjnych biografii wydanych w roku 2011: Czesława Miłosza, napisanej przez Andrzeja Franaszka, oraz Janusza Korczaka, pióra Joanny Olczak-Ronikier. Potwierdzając potoczne przekonanie o zapotrzebowaniu na "nowe” biografie, wskazywała, iż szczególne zainteresowanie budzą dziś biografie osób o „rozłamanej”, podwójnej, czy nawet wielokrotnie rozszczepionej tożsamości. Po przełomie roku 1989 wyraziście artykułowaną koniecznością stało się (obok rozpoznania najszerzej pojmowanych „doświadczeń kresowych") podjęcie tematu polsko-żydowskich i żydowsko-polskich losów, tragicznie (najczęściej) splątanych biografii determinowanych przez Historię wieku XX, życiorysów „granicznych" w podwójnym znaczeniu: poświadczających istnienie niewyleczonej (nieuleczalnej) traumy historycznych doświadczeń granicznych oraz bytowania na granicy kultur, pomiędzy społecznościami, na obrzeżach wspólnot.

Jawnie dziś ewokowane osobiste zaangażowanie pisarzy w podejmowane biograficzne tematy, rezygnacja z konwencji „odtwarzania tylko obiektywnych faktów" sprawia, iż biografie jako podwójne świadectwo doświadczeń bohatera i autora stają się wyrazistą diagnozą nie tylko przeszłości, ale i teraźniejszego jej oglądu. Olczak-Ronikier swoją opowieść o Korczaku opatrzyła podtytułem Próba biografii, jakby jej bohater ostatecznie wymknął się jednoznacznemu osądowi oraz „bezlitosnemu”, a z założenia pozbawionemu mitologizacyjnych przesłon, spojrzeniu autorki (skądinąd córki Hanny Mortkowicz-Olczakowej, autorki pierwszej powojennej biografii Doktora). GrudzińskaGross określenie „próba” pojmuje jako wskazanie z jednej strony na niewielką ilość materiałów źródłowych, utrudniającą stworzenie pełnego portretu - Korczak niezmiennie pozostaje postacią niezwykle tajemniczą, z drugiej zaś na rzeczywistą niemożność odtworzenia świata, który zginął bezpowrotnie w gruzach cywilizacyjnej katastrofy. Być może jednak istotniejsze jest wyczuwalne w całym tomie napięcie między istniejącą legendą Korczaka

Matywieckiego (2007), drugiej - niech mi wybaczą jej miłośnicy - Oskarżona Wiera Gran Agaty Tuszyńskiej (2010). Zwraca uwagę fakt, iż wskazane przez Śliwińskiego przykłady to biografie (i autobiografie) rejestrujące doświadczenie rozszczepionej tożsamości. 
bohatera a przeciwstawianą jej nieustannie „nową” biografią: pedagoga-masona, zmagającego się z depresją samotnika, Żyda, polskiego pisarza.

Inaczej - choć jedynie z pozoru - kwestię rozziewu między biograficznymi faktami a pomnikowym wizerunkiem Korczaka postrzegał kilka dekad wcześniej Igor Newerly, przedwojenny sekretarz Henryka Goldszmita, jego współpracownik i przyjaciel. Zaginione podczas wojny notatki, jak twierdził, mogłyby posłużyć nadaniu wspomnieniom jednolitego kształtu literackiego - powieści biograficznej, studium, których autorem Newerly pragnął zostać. Zawsze jednak teksty Ucznia przekształcały się w zapis osobistego doświadczenia w obcowaniu z Mistrzem: z niezwykłym, mimo że trudnym w codziennym obcowaniu, człowiekiem i z akceptowaną legendą bohaterskiego do ostatniego tchnienia opiekuna sierot. Newerly, świadom tego, przyznawał: „Był czas, gdy kochając Cię buntowałem się, wynajdywałem dziwactwa Twe i błędy, i rzeczy nieporadne, żeby się tylko wyzwolić spod Twego wpływu i wyżyć w czymś własnym” ${ }^{5}$. Newerly, który o „błędach i nieporadnościach” Korczaka musiał wiedzieć więcej niż inni, opisywał go przede wszystkim z perspektywy osobistego żalu z powodu niepowetowanej straty oraz wyrzutów sumienia wynikających z poczucia, że zawiódł, tego, którego uważał za duchowego przewodnika. Znany mu ludzki wymiar wszelkich słabości Doktora nie stanowił dla autora Pamiątki z Celulozy przeszkody $\mathrm{w}$ świadomym współtworzeniu heroicznej legendy Korczaka. Stał się jej gorliwym orędownikiem, jednak nie tylko z przyczyn osobistych; istnienie tej legendy było dla niego także konieczną spłatą moralnej powinności bezsilnych świadków wobec niewinnych ofiar Zagłady.

Anna Nasiłowska (autorka dwóch „niepoprawnych biografii”: portretu podwójnego Jeana-Paula Sartre'a i Simone de Beauvoir oraz Marii Pawlikowskiej-Jasnorzewskiej) w swoich rozważaniach o istocie przemian biografistyki stwierdziła, iż dzisiaj biografia to „opowieść o zmienianiu się, przechodzeniu przez kolejne etapy życia i twórczości, niewierności wobec siebie i wiecznym poszukiwaniu, a nie umoralniająca bajeczka z pozytywnym bohaterem" ". Nasiłowska słusznie protestując przeciwko kreowaniu retuszowanych portretów o dydaktycznym przesłaniu, zdaje się nie dostrzegać faktu, iż „portrety nie retuszowane”, również mogą służyć celom innym niż docieranie do biograficznej „prawdy". Zwłaszcza wtedy, gdy wyrastają z poczucia powinności wo-

\footnotetext{
5 I. Newerly, Żywe wiazanie, Warszawa 1966, s. 29.

${ }^{6}$ A. Nasiłowska, Herezje, „Teksty Drugie” 2010, nr 1-2, s. 136.
} 
bec zmarłych, potrzeby oddania sprawiedliwości odchodzącym w zapomnienie ofiarom Holocaustu.

Autorka książki Korczak. Próba biografii, przystępując do zmagań z życiorysem Doktora, tak postrzegała swoje zadanie: „Zależało mi na tym, by pokazać etapy drogi, jaką przeszły kolejne pokolenia, nim Henryk Goldszmit stał się Januszem Korczakiem i polskim pisarzem. Dziadkowie - polscy Żydzi. Rodzice - Żydzi spolonizowani. On sam Polak-Żyd. Zawsze podkreślał swoją podwójną tożsamość" 7 . Jednak Olczak-Ronikier przede wszystkim świadomie nie stroniła od osobistego zaangażowania, wielokrotnie wypełniając luki w biografii Doktora wspomnieniami własnymi i opowieściami z dziejów swojej rodziny ${ }^{8}$ (ta strategia sprawiła, iż Irena Grudzińska-Gross określiła Korczaka jako „książkę historyczną z elementami autobiografii autorki" 9 ). Tym samym starała się uwypuklić to, co wspólne i ponadjednostkowe w doświadczeniu egzystencji obciążanej podwójną tożsamością. Empatia widoczna w interpretowaniu losu Doktora ufundowana była na podobieństwie doświadczeń znanych z historii rodzinnych, a rozszerzona została na wszystkich naznaczonych podobnym losem.

Janina Abramowska, badając reguły konstruowania „biografii empatycznych", w których prezentowany (kreowany) życiorys służy także osobistym wyznaniom autora, wskazywała na ich niezbywalną wartość poznawczą. Biografia empatyczna, choć „skażona” gestami kreacji i autokreacji, pozostaje zapisem ważnym, także w wymiarze wspólnotowym:

„Prawda” biograficzna (tak samo jak autobiograficzna) jest zawsze wątpliwa, migotliwa, świadomie i nieświadomie zafałszowana [...]. Ale i o taką ułomną prawdę świadomości warto się starać, bo jest ona osobistym i zbiorowym Świadectwem. A dawać świadectwo własnemu czasowi można także w sposób zapośredniczony, poprzez konfrontację z epoką minioną ${ }^{\mathrm{IO}}$.

Potrzebę dawania świadectwa przeszłości przekształcanej w opowieść o cudzej biografii można więc pojmować także jako

7 Ibidem, s. 11.

${ }^{8}$ Joanna Olczak-Ronikier jest autorką książki Wogrodziepamięci (Kraków 2001), która została złożona z odtworzonych życiorysów członków rodziny niezwykle istotnym elementem każdej biografii okazywało się (zmieniające się $\mathrm{w}$ czasie, w różnym stopniu uświadamiane) poczucie podwójnej przynależności do wspólnoty polskiej i żydowskiej, a zarazem poczucie wykluczenia z obu tych wspólnot.

9 I. Grudzińska-Gross, op.cit., s. 15.

ro J. Abramowska, JózefHen - biografempatyczny, w: eadem, Rekonstrukcje i konstrukcje. Studia literackie, Poznań 2003, s. 198. 
nieodparte dążenie do zrozumienia i zinterpretowania czasu teraźniejszego. Takie świadectwa zatem, wyrastając z najbardziej osobistych pobudek, okazują się determinowane przez aktualne (choć zawsze hipotetyczne) potrzeby odbiorców i włączają się $\mathrm{w}$ istniejące $\mathrm{w}$ danym czasie reguły zbiorowej komunikacji. Różniąc się między sobą, jednocześnie niezależnie od wszelkich okoliczności - rangi pisarza, założonych celów, podejmowanych przezeń wyborów światopoglądowych i artystycznych czy osadzenia w określonym momencie powojennej historii literatury stają się wypełnieniem nadrzędnej dyrektywy przeciwdziałania niepamięci.

Na początku drugiej dekady XXI w. powstały dwa niezwykle interesujące utwory, w których odtwarzanie (kreowanie) losów przodków służy reinterpretacji przeszłości, a zarazem wpisuje się w dyskusję o polsko-żydowskich i żydowsko-polskich relacjach toczącą się w teraźniejszości. Mowa o Wtoskich szpilkach Magdaleny Tulli i Pensjonacie Piotra Pazińskiego. Świadomość niemożności znalezienia języka zdolnego udźwignąć temat Zagłady nie skłoniła autorów do milczenia, lecz właśnie do ponowienia gestu odczytywania własnej tożsamości przez podjęcie próby opisania tragicznie splątanych rodzinnych losów. Biografie przodków odtwarzane przez zapis doświadczenia obcowania z nimi, zmagania się z ich nieprzezwyciężalną traumą, przez nieudane - bo ostatecznie niemożliwe - wysiłki przeniknięcia ich bolesnych doznań wiodą ku odkrywaniu tajników własnej biografii. Autorzy przynależący do dwóch różnych pokoleń, w różnym stopniu dotknięci traumą Zagłady, przekonują w swych utworach o jej nieusuwalnym istnieniu, w wymiarze jednostkowym i zbiorowym. Jednocześnie epoka gomułkowska i dekada rządów Gierka zostały opisane z innej perspektywy - powojenna historia Polski jest w tych utworach historią nie tyle wymazywania pamięci, co jej unieważniania przez zbiorowość, w realności powszechnego obojętnienia na wymiar cywilizacyjnej katastrofy, a nade wszystko ignorowania jej skutków.

Magdalena Tulli stworzyła we Wtoskich szpilkach przejmujące świadectwo dziedziczenia nieusuwalnej traumy determinującej życiorysy strzaskane przez zbrodnię Holocaustu. Niepojmowalny wymiar traumy poświadcza wizja egzystencji określonej przez to doświadczenie graniczne także w drugim pokoleniu. Utwór jawnie autobiograficzny zapada w pamięć nie tylko jako wiwisekcja dokonywana na własnym losie, ale i jako wysiłek rozpoznania tożsamości naznaczonej nieusuwalnym piętnem - biografią matki. Stąd zapewne głównymi bohaterkami utworu stały się trzy postaci: matka, mała dziewczynka cierpiąca z powodu niepoję- 
tego odrzucenia jej przez „najbliższą osobę” i dorosła narratorka tych przejmujących opowieści, usiłująca odtworzyć emocjonalny „porządek” zdarzeń. Nie dochodzi do uwspólnienia doświadczeń dziewczynki i dojrzałej kobiety, choć starsza może wywołać w sobie wizję opiekowania się, chronienia, czułego wsparcia okazywanego sobie sprzed lat.

Relacje łączące bohaterkę $\mathrm{z}$ matką również pozostają $\mathrm{w}$ dwóch niemożliwych do połączenia sferach. Oschła, pozbawiona emocji, a nawet zdolności nawiązania jakiegokolwiek kontaktu z córką elegancka kobieta w szpilkach majaczy na obrzeżach pamięci o trudnym, samotnym, smutnym dzieciństwie wciąż i wszędzie doznającej poczucia odrzucenia dziewczynki. Stara, zniszczona przez chorobę Alzheimera matka staje się podopieczną dorosłej córki - dopiero ze zniszczonego uwiądem umysłu matki córka może uzyskać informacje o jej przeszłości, które pozwolą przekroczyć próg obcości (i to pomimo ponownego odrzucenia, chora żyje bowiem w przekonaniu, że nigdy nie miała dzieci).

Jednocześnie związek między bohaterkami przekracza granice śmierci. W testamencie matki znalazła się wyraźna dyrektywa: „[...] na wypadek śmierci: żadnego pogrzebu, żadnego grobu. Ciało spalić w krematorium. Brakowało tylko dyspozycji, co zrobić z popiołem. Widocznie nie przyszło jej do głowy, że zbiorą ten popiół i oddadzą w urnie". Reakcja córki poświadcza skomplikowaną naturę tego związku: „Póki nie wpadnę na właściwy pomysł, będę ją przechowywać nielegalnie w mieszkaniu. Co jakiś czas znajduję dla niej nowe miejsce, zawsze tak samo nieodpowiednie" ${ }^{\text {II }}$.

Magdalena Tulli kreuje zarazem w swoim utworze wizję skutków, jakie przyniosła Zagłada dla zbiorowości przez Shoah zdeterminowanej:

Energia przemocy przekształciła się w błądzącą bez celu i kierunku energię cierpienia żalu i nienawiści. I w tej postaci przechodzi na własność następnych pokoleń, czy tego pragną, czy nie. [...] Nikt nie jest jej Panem. To ona, energia żalu i nienawiści, pamięć poniżenia, bierze nas w obroty i nie wiemy już sami, za kogo mamy się uważać. Wiemy tylko, że jesteśmy na minusie ${ }^{\mathrm{I2}}$.

Ewa Wiegandt - pisząc o obecnym we wcześniejszym utworze Tulli (Skaza, 2009) efekcie estetycznym, którym jest wrażenie miniaturyzacji, ucodziennienia, infantylizacji świata (oznacza-

\footnotetext{
${ }^{\text {II }}$ M. Tulli, Wtoskie szpilki, Warszawa 2011, s. 78.

${ }^{12}$ Ibidem, s. 65.
} 
jących przede wszystkim naiwną postawę poznawczą, waloryzowaną dodatnio) oraz zasadzie „im większe pomniejszenie reprezentacji, tym więcej mieści się znaczeń" - podkreśla więź autorki z tradycją: „Tulli wpisuje się w obrazoburczy i skandaliczny sposób pisania o Zagładzie, ten, któremu patronują Borowski, Miłosz, Białoszewski. Borowski patronowałby uzwyczajnieniu, Miłosz «głosom biednych ludzi», Białoszewski - dziecięcości” ${ }^{33}$. We Wtoskich szpilkach owa naiwna postawa poznawcza zderza się gorzką wiedzą o przeszłości, a tym samym współtworzy skrajnie pesymistyczną wizję teraźniejszości:

Kolumna stoi na placu, potem znika, potem nad placem wisi czarny dym. Choć w rzeczywistości kolumna nie znika nigdy i czarny dym także nigdy nie znika. Ten plac, przecięty granicą między światami, jest miejscem, z którego nie da się odejść, choć z drugiej strony nie sposób w nim żyć ${ }^{14}$.

Przemysław Czapliński tak ujmował skomplikowane relacje panujące niegdyś w literackich, jawnie tekstowych, często „szeleszczących papierem" światach tworzonych przez Tulli:

[...] w świecie makiet i scenografii nadal można ginąć i zabijać śmierć (własna lub cudza) stanowi bowiem iluzoryczne zatrzymanie procesu przekształcania się twardej rzeczywistości w materię składającą się z metafor. Zatrzymać proces „upłynniania” rzeczywistości to odmówić uznania, że obraz świata jest wytworem naszej świadomości i że my ponosimy za niego odpowiedzialność ${ }^{15}$.

Podjęcie tematu Zagłady oraz własnych, wyznaczonych przez jej ciągłe trwanie doświadczeń zmusza i autorkę, i odbiorców do weryfikacji komunikacyjnych strategii. Dlatego też kiedy Tulli z ironią wskazuje dwa (jedynie) dostępne potomkom ofiar Holocaustu sposoby reagowania na dziedziczoną traumę „Trudno powiedzieć, co lepsze - fobia czy fiksacja, i którą z tych dwóch strategii należałoby zalecać spadkobiercom" ${ }^{{ }^{6} 6}$ - czytelnik

${ }_{3}$ E. Wiegandt, Postmodernistyczne alegorie Magdaleny Tulli, w: eadem, Niepokoje literatury. Studia o prozie polskiej XX wieku, Poznań 2010, s. 240. Badaczka rozważa dalej specyfikę ironii używanej przez Tulli, której obce jest właściwe podmiotowi ironicznemu poczucie wyższości, chociaż pozostaje jej sedno: „ostrość widzenia, możliwość uzyskania dystansu do przemijalności, do wykpionej formy powieściowej, a także do samej ironii” (ibidem, s. 242).

${ }^{4}$ M. Tulli, op.cit., s. 69.

I5 P. Czapliński, Polska do wymiany. Późna nowoczesność i nasze wielkie narracje, Warszawa 2009, s. 355.

${ }^{\text {I6 }}$ M. Tulli, op.cit., s. 64. 
dostrzega $\mathrm{w}$ tej wypowiedzi przede wszystkim prawdę osobistego świadectwa i próbę zakreślenia uniwersalnej ramy dla niemożliwych do zinterioryzowania doświadczeń. Wszechobecna w utworze śmierć nigdy nie poznanych, niezliczonych krewnych staje się tym samym niepodważalnym faktem i nieusuwalnym ze zbiorowej pamięci znakiem przeszłości.

Inaczej - choć znów jakby jedynie z pozoru - odtwarza utraconą przeszłość Piotr Paziński, nie syn, lecz wnuk dotkniętych traumą Zagłady. Utwór rozpoczyna sekwencja podróży warszawską kolejką podmiejską: młody wędrowiec rejestruje wówczas zmiany zapamiętanych z przeszłości miejsc - dla niego bowiem wyprawa do znajdującego się na linii otwockiej uzdrowiska (które jeszcze przed wojną zostało uznane przez żydowską społeczność za własne) jest powrotem do czasów dzieciństwa, z jednej strony do historycznie ukonkretnionej „epoki Gierka”, z drugiej zaś do „genialnej epoki” poznawania świata.

Spotkane na progu domu wypoczynkowego staruszki a może tylko ich widma $\mathrm{z}$ minionego czasu - to $\mathrm{z}$ pozoru typowe starsze panie, bezradne, zagubione w niezrozumiałej rzeczywistości, tracące pamięć, samotne i smutne. Ich widok przywołuje wspomnienia sprzed lat: „Gadają jeden przez drugiego, że trudno zrozumieć. Głosy z widowni. Czy wy możecie na chwilę przestać? Kłócą się w kółko, jakby było o co [...]. Gdzieś tam i pani Tecia, w środku tego harmidru, z porcją najświeższych gazet do biblioteki pana Abrama" ${ }^{17}$. Rozgardiasz i bezcelowe spory ukazywane z perspektywy niewiele rozumiejącego dziecka tworzą mimo wszystko aurę swoistej beztroski. Przedmiotem przyjacielskich przecież kłótni są problemy związane z zakwaterowaniem czy wyżywieniem, znajomy zgiełk nie burzy poczucia bezpieczeństwa, lecz stanowi tło doraźnych dyskusji o lokalnej polityce.

Zaludniający Pensjonat staruszkowie, zazwyczaj portretowani jako naznaczone cierpieniem, uwiądem i rozpadem istoty, są zarazem ostatnim pokoleniem pamiętającym czas sprzed cywilizacyjnego kataklizmu, ostatnim ogniwem wielowiekowej kultury zmiecionej przez wojenne zawieruchy z powierzchni ziemi, ostatnimi depozytariuszami pamięci, ocalającymi jej ślady. Jeden z bohaterów, pan Jakub, wspomina z żalem: „Nasi mędrcy. Iluż ich było. Wszyscy zatopieni w literach. [...] powiedziane jest: mędrzec idzie przed królem. Więc każdy ma ochotę być mędrcem. To jest normalne. Tyle że natenczas można było w tych mędrcach przebierać jak w dorodnych śliwkach” (s. 62-63). Różnica mię-

${ }_{7}$ P. Paziński, Pensjonat, Warszawa 2010, s. 13-14. W artykule po cytatach będę podawała numer strony odnoszący się do tego wydania. 
dzy czasami przedwojennymi a schyłkowym PRL-em polegałaby więc również na tym, że w latach 70 . ocalała już tylko pamięć postawy życiowej tożsamej z dążeniem do wiedzy i poznania tajemnic istnienia, postawy, której hołdowało niegdyś tak wielu, a która została zachowana jedynie przez nielicznych, starzejących się strażników tejże pamięci.

Młody bohater-narrator chce dochować wierności zarówno wspomnieniom świadków minionego czasu, jak i swoim wspomnieniom o ich skarlałej, lecz wciąż godnej egzystencji. Paziński autor podąża - być może bezwiednie - śladami Emanuela Levinasa propagującego lekturę żydowskiej tradycji, która pozwala jednocześnie zachować samoświadomość wspólnoty oraz uczynić ją wartością uniwersalną. Levinas twierdził:

W przeszłości, istotnie, należy rozróżnić dwie strefy: tę, która zdecydowanie należy do historii i staje się zrozumiała jedynie w zapośredniczającej, uczonej i krytycznej interpretacji historyka oraz niesie ze sobą nieuchronnie wymiar mityczny, i tę, która należy do późniejszej epoki i która określa fakt związania z rzeczywistością i jej rozumieniem w sposób bezpośredni ${ }^{\mathrm{I} 8}$.

Zadaniem „późniejszej epoki” - naszej epoki - byłoby zatem uczynienie zrozumiałą i bliską przeszłości, która kostnieje w opracowaniach i mitach, tracąc ludzki, a więc uniwersalny wymiar doświadczenia. Paziński, skonstruował opowieść o starych ludziach, których istnienie ukształtowało wrażliwość dziecka, zbierającego okruchy cudzych wspomnień, by w przyszłości także dzięki nim - określić własną tożsamość.

W świecie Pensjonatu często powtarzane są frazy: ,ze starymi nudno”, ,ze starymi smutno”. Dla starszych gości pobyt w domu wypoczynkowym pozostaje jednak atrakcją ${ }^{\text {I9 }}$, chwilową ucieczką od zwyczajnego życia, przestrzenią, w której można spotkać „swoich”, podobnie, choć w sposób równie niepojęty, ocalonych $\mathrm{z}$ katastrofy. Wizyta młodego bohatera przyjmowana jest natomiast ze zdziwieniem, a nawet nieufnością - powinien bowiem całym sobą przynależeć do cywilizacji „,czasu przyspieszonego”.

W utworze Pazińskiego starość uosobiona w żydowskich mieszkańcach pensjonatu - przypominającym uzdrowisko „Śródborowianka” znane autorowi z wakacji w czasach dzieciń-

I8 E. Levinas, Cztery lektury talmudyczne, przeł. E. Burska, Kraków 1995, s. 9.

r9 Odmiennie wykreowana została wizja domu starców w powieści Zyty Rudzkiej Ślicznotka doktora Josefa (Warszawa 2006), w którym to niegdysiejsze dzieci ocalone z Holocaustu zostały przymusowo - tak jak w obozie śmierci zamknięte w oczekiwaniu na ostateczny wyrok. 
stwa $^{20}$ - pozostaje wartością niezbywalną. Podwójnie wykluczeni - i jako jedyni ocaleni z Zagłady, którzy pozostali w kraju urodzenia, i jako niepotrzebni społeczeństwu starcy - jednak opierają się wszelkim przeciwnościom. Przykładem może być historia pana Abrama, podobna do wielu innych:

Pan Abram stracił w czasie wojny całą rodzinę. W obozach i w getcie. Został tylko syn pana Abrama i już. Mały był, to się udało gdzieś tam przechować [...]. I ten syn potem pojechał. Pan Abram został.

- Ktoś musi pilnować kości - powtarzał twardo. (s. 41)

Pilnowanie nieistniejących grobów urasta do rangi straceńczej, a zarazem traktowanej w wymiarze jednostkowego obowiązku, misji. Jedyne dziecko wśród wielu starych ludzi poznawało niejako w sposób naturalny wagę spraw minionych, młody człowiek, który po latach odwiedził opustoszały pensjonat pełen widm, poczuwa się do obowiązku zachowania pamięci o umarłych.

Pesymistyczny wymiar narracji o podjętej decyzji przyłączenia się do wspólnoty utraconych, zaginionych, rozproszonych i odchodzących w niepamięć przynosi równolegle prowadzona opowieść o rzeczach. Wraz ze śmiercią właścicieli i one zaczynają rozsypywać się w proch, niszczeć, a nade wszystko gubić sens wcześniej im nadawany przez przynależność do konkretnych osób i biografii. Paczki zetlałych listów, wyblakłych fotografii, dokumentów, choć cudem ocalone $\mathrm{z}$ wojennej pożogi, stają się zbędnym, bo nieczytelnym dla potomnych, świadectwem rozpadu dawnego świata. Stąd pomysł, by i rzeczom urządzić godny pochówek w ziemi. Śmierć ostatniego potomka zdolnego rozpoznać ich twarze będzie przecież i ich ostateczną zagładą:

Kiedy i mnie zabraknie, oni na papierowych odbitkach staną się tylko przeszłym, nieznanym thumem, zbiorowiskiem obcych niewyrazistych twarzy, jak te z portretów sprzedawanych za grosze na targach staroci [...], lepiej pochowam ich w ziemi, na dnie parowu [...]. Tam już na pewno nikt ich nie znajdzie, tam ich przykryje i otuli do snu puszysty piach. (s. 126)

Decyzja o zarejestrowaniu ich historii, spleceniu jej z własną biografią może zatem okazać się decyzją ważącą nie tylko na dookreślaniu własnej tożsamości, ale i ocalaniu strzępów tożsamości

${ }^{20}$ Piotr Paziński w wielu wywiadach podkreślał autobiograficzny charakter opowieści, wskazywał jednak na swoją głęboko zakorzenioną potrzebę ucieczki od faktograficznej wierności. Literackie poszukiwanie tożsamości domaga się aktów kreacji. 
wymierającej wspólnoty. I choć zadanie takie zdaje się przekraczać siły jednego opowiadającego, uginającego się pod ciężarem niespójnych obrazów oraz trudnych do rozszyfrowania zdań chociaż nie bywa ukazywane w wymiarze gestu heroicznego musi zostać podjęte i bywać podejmowane wciąż od nowa.

Egzystencja $\mathrm{w}$ wieku podeszłym również nie podlega idealizacji. To raczej mężne trwanie na przekór wszelkim przeciwnościom losu, na przekór wyrokom Historii, staje się istotą zaakceptowanego modelu życia:

Pan Leon, pan Abram, babcia i pani Tecia. Ze swoim piętnem tego, co było i co z chwilą, kiedy odeszli, na powrót zapadło się w nicość. Ich życie i moje, wśród cieni, pośród duchów i z duchami - zamiast promieni świeżego słońca. Za to gorzki smak przemijania. [...] Krajobraz melancholijny. Tak już musi być. Pewnie całkiem odwrotnie, niżby życzyli sobie oni, którzy wprowadzali mnie w świat i mieli ambicję wskazywać drogę. (s. 74)

Zgoda na podjęcie roli kontynuatora dzieła zmarłych przodków, strażnika pamięci i kolekcjonera reliktów przeszłości określa perspektywę postrzegania, a zatem także opisywania minionego czasu. Narrator-bohater nie buntuje się przeciw zadaniu pojmowanemu jako gest samostanowienia, tym samym obraz świata, który go ukształtował, nabiera cech idylli. Zdarzenia z przeszłości jawią się jako najważniejsze doświadczenie - podobnie spisywanie opowieści o nich staje się doświadczeniem uobecniania, tego, co okazało się najistotniejsze w kształtowaniu tożsamości. Marek Zaleski w rozprawie Echa idylli przekonywał:

Fantazja (i fikcja będąca jej wytworem) jest mostem łączącym sztukę z tym, co nieświadome. W koncepcji Freudowskiej jest spełnieniem życzenia/pragnienia, które w przedstawieniu literackim znajduje swój wyraz. Dla fantazjującego podmiotu ów przedmiotowy korelat życzenia, jego reprezentacja, zyskuje wymiar egzystencjalny, staje się częścią doświadczenia ${ }^{2 \mathrm{I}}$.

Świat przedstawiony Pensjonatu zaludniają postacie przynależące do różnych czasoprzestrzeni i różnych porządków ontycznych. Wyobrażenia przedwojennych gości podwarszawskich uzdrowisk sąsiadują z postaciami wykreowanymi ze wspomnień $\mathrm{z}$ lat 70 . oraz widmowymi istotami o całkiem niepewnym sta-

${ }^{21}$ M. Zaleski, Echa idylli w literaturze polskiej doby nowoczesności i póżnej nowoczesności, Kraków 2007, s. 317. 
tusie - jakby jednocześnie funkcjonowały w przeszłości i dniu dzisiejszym, choć przeczy to zasadzie prawdopodobieństwa. Do teraźniejszości zdaje się należeć jedynie sam narrator oraz ponury, przepełniony goryczą kierownik pensjonatu. Gęstniejąca z każdym rozdziałem mgła również wpływa na rosnącą fantasmagoryczność kreowanej wizji, która jest zarazem groteską i idyllą, oniryczną fantazją i zdradzającą swą subiektywność materią wspomnień.

Lektura zależy od obranej perspektywy odbioru - z jednej strony bowiem narrator sygnalizuje podobieństwo własnej biografii z biografią autora (czasem sugeruje ich tożsamość), $\mathrm{z}$ drugiej zaś autor, $\mathrm{w}$ wyraziście stylizowanej i intertekstualnie kształtowanej wypowiedzi, podkreśla fikcjonalny wymiar tekstu. Pensjonat jest więc zarazem racjonalnie kształtowaną wypowiedzią autobiograficzną, jak i oniryczną fantasmagorią, której źródła tkwią w tym, co nieświadome. Zaleski widział w takim ukształtowaniu tekstu cechę charakterystyczną przedstawienia idyllicznego:

Fikcjonalność stanowi agendę fantazji. W przedstawieniu łączy to, co imaginacyjne i wywodzące się często z nieświadomości, z tym, co świadome i poddane racjonalizacji. Iser zwraca uwagę, że fikcja literacka, $\mathrm{z}$ jaką mamy do czynienia $\mathrm{w}$ idyllicznym przedstawieniu, często przyjmuje postać snu [...]. Ten charakter sceny przedstawienia jako konwencja derealizacji i „podwojenia” znaczenia zdarzeń: ułatwia wprowadzenie persony literackiej będącej czymś pośrednim między rzeczywistą osobą a maską ${ }^{22}$.

Inny aspekt swoistej „potrzeby snu”, wykorzystania języka onirycznego w przedstawianiu najtrudniejszych doświadczeń, dostrzegała Cathy Caruth, uznawana za założycielkę nowego nurtu w badaniach nad traumą w humanistyce. Badaczka przekonywała: „Można powiedzieć, że język marzenia sennego (jako model dla języka traumy) to żądanie odbiorcy, słuchacza, który będzie słuchać inaczej. To moment literacki, w którym musi dojść do wynalezienia języka już niebędącego językiem świadomości” ${ }^{23}$. Tak wypowiedziana prawda nie będzie prawdą świadomości, ponieważ - jak twierdzi Caruth - „Nie można jej przełożyć na kategorie gramatyczne, które konstatują prawdę o przeszłych wydarzeniach" ${ }^{24}$. Będzie natomiast zbliżeniem się do prawdy do-

22 Ibidem, s. 319.

${ }_{23}$ Teoria traumy jako siła lektury. Catby Caruth w rozmowie z Katarzyna Bojarska, „Teksty Drugie” 2010, nr 6, s. 129.

${ }^{24}$ Ibidem. 
świadczenia niewyrażalnego. Może stać się również projektem odkrywania prawdy o traumie zapośredniczonej, odziedziczonej, poznawanej w strzępach niekoherentnych, a na dodatek polifonicznie nakładających się na siebie opowieści.

Piotr Paziński reprezentuje trzecie pokolenie po Zagładzie, podobnie jak jego bohater, wnuk Bronki, który jest $\mathrm{z}$ pokolenia wnuków ofiar Holocaustu. Postmemorialne przypomnienie jako dobrowolnie podjęte zadanie twórców określonych przez swoją rodową i pokoleniową przynależność wpisuje się w długą już historię zjawiska postpamięci i wyrosłej na jego gruncie twórczości. Teksty przynależące do tego nurtu zdaniem Bartosza Dąbrowskiego ,alegoryzują kulturowy tekst zagłady, odsłaniając jego rzekomą historyczność jako przestrzeń rekonstruowanego znaku lub inscenizowanego sensu" ${ }^{25}$. O Pensjonacie badacz pisał: „Żydowska przynależność, odtwarzana przez pamięć, jawi się w tym przypadku, jako rozpięta między pustką i mnogością zrekonstruowanych obrazów, łamliwym amalgamatem wspomnień i projekcji” ${ }^{26}$. Jednak utwór Piotra Pazińskiego nie ma na celu prowadzenia ironicznej gry z przeszłością czy tworzenia kolejnego wariantu kulturowej opozycji starości i młodości, ani nawet nostalgicznego rekonstruowania źródeł prywatnej mitologii - niemniej wszystkie te elementy można odnaleźć w tkance powieści.

W końcowych partiach tekstu pojawia się jako wyrazista coda, istotna dla interpretowania całości twórczego zamysłu, projekcja spotkania bohatera z przodkami. W nocnej, leśnej scenerii rozgrywa się dramat odrzucenia wnuka Bronki przez wspólnotę widm, zjaw i majaków. Doprowadzony na polanę w głębi lasu przez pana Jakuba (pozostającego do końca istotą na wskroś tajemniczą, nieprzypadkowo obdarzoną imieniem patriarchy narodu żydowskiego) bohater zostaje poddany zbiorowemu osądowi. Otoczony przez duchy czuje ich przykuwającą do ziemi siłę, a zarazem nieusuwalną jedność z nimi - „jak gdybym należał do pokolenia pana Abrama i pani Mali, jakby pomiędzy mną a wujem Szymonem nie było żadnej różnicy wieku, chociażby najmniejszej szczeliny, która mogłaby nasze losy od siebie oddzielić" (s. 134).

${ }_{25}$ B. Dąbrowski, Postpamięć, zależność, trauma, w: Kultura po przejściach, osoby z przeszłościa. Polski dyskurs postzależnościowy - konteksty i perspektywy badawcze, red. R. Nycz, Kraków 2011, s. 262. Dąbrowski przekonuje dalej: „Zasadniczą rolę w tych utworach odgrywa żywioł wielopostaciowej, silnie wyeksponowanej ironii, która jawnie podważa «twardy» status historycznego świata przedstawionego i odsłania go jako przestrzeń literackiej gry”.

${ }^{26}$ Ibidem, s. 267. 
Tłum zjaw, także tych z najdalszej przeszłości, błaga Boga tylko o jedno, o „przerwanie łańcucha okaleczonych pokoleń”, natomiast wnukowi Bronki nakazuje opuszczenie lasu, przestrzeni, którą uznaje za własną i której nie chce z nikim dzielić. Decyzja tych wszystkich, którzy na koniec niespodziewanie objawiają się jako ostatni z patriarchów, wydaje się definitywna i - przynajmniej w świecie przedstawionym utworu - nieodwołalna. „Ostatni z łańcucha pokoleń, uczepiony na samym końcu” samotnie wyrusza więc na stację kolejową - by wrócić do swojego miejsca i czasu. Pozostaje pytanie, gdzie będzie mógł to własne miejsce odnaleźć, a nawet czy ono naprawdę istnieje.

Lektura opowieści, tych, które tylko pośrednio związane są z traumą doświadczenia Holocaustu, z niemożliwą do uporządkowania czy rekonstruowania w kategoriach przyczynowoskutkowych pamięcią o cywilizacyjnej katastrofie, skłania nie do podsumowań, lecz do stawiania pytań. Zmagania z oporną materią języka niezdolnego pomieścić doświadczenia są udziałem nie tylko autorów, ale i komentatorów. Ponawiane - we wciąż zmieniających się warunkach kulturowych, historycznych i komunikacyjnych - gesty kreowania biografii polsko-żydowskich i żydowsko-polskich wyrastają $\mathrm{z}$ najgłębszej potrzeby rozpoznania naszej przeszłości i teraźniejszości. Kolejne realizacje poświadczają jednak także niemożność rozumowego pochwycenia ich przebiegów, wymazania znaczeń, jakimi zostały obciążone, zamknięcia serii - tym samym interpretowanie rozrastającego się nieustannie zbioru tekstów musi pozostawać ciągle ponawianym rekonesansem, próbą porządkowania lekturowych (a więc także egzystencjalnych i emocjonalnych) doświadczeń.

\section{AgNiESZKa CZYŻaK}

\section{Polish-Jewish and Jewish-Polish Biographies: Repeated Reconnaissance}

The article contains reflections on changes in biographical writing, especially biography of persons of heterogenous ethnic identity. The biographies are not only reconstructions of an individual's life, but also a clear testimony and reflection of changes in collective consciousness. It turns out that biographies also discover, in a peculiar way, the author's identity, who, in the process of selection and creation of a biographical text, reveals a part of their own history. This aspect is clearly seen in texts by second and third generation Holocaust survivors, and is demonstrated by interpretations of Magdalena Tulli's Wtoskie szpilki [Italian High Heels] and Piotr Paziński's Pensjonat [Boarding house]. 
Keywords: Polish-Jewish and Jewish-Polish biographies, postmemory, Holocaust, family histories, identity, testimony.

Agnieszka Czyżak - doktor habilitowany, adiunkt w Zakładzie Poetyki i Krytyki Literackiej Instytutu Filologii Polskiej UAM. Współredaktorka tomów zbiorowych, m.in. Powroty Iwaszkiewicza (1999), PRL - świat (nie) przedstawiony (2010), Elementy do portretu. Szkice o twórczości Aleksandra Wata (2011). Autorka książek Życiorysy polskie 1944-1989 (1997), Kazimierz Brandys (1998), Na starość. Szkice o literaturze przełomu tysiącleci (2011). 